\title{
The work and equipment for earth magnetism and meteorology of the German South Polar expedition, and suggestions for international co-operation during the time of the South Polar research, 1901-1903
}

\section{Dr. Fr. Bidlingmaier}

To cite this article: Dr. Fr. Bidlingmaier (1901) The work and equipment for earth magnetism and meteorology of the German South Polar expedition, and suggestions for international co\#operation during the time of the South Polar research, 1901-1903, Scottish Geographical Magazine, 17:9, 467-470, DOI: 10.1080/00369220108733279

To link to this article: http://dx.doi.org/10.1080/00369220108733279

\section{Published online: 27 Feb 2008.}

\section{Submit your article to this journal $\longleftarrow$}

\section{Article views: 3}

a

View related articles

Citing articles: 1 View citing articles 
1896. Grönland und der Nordpol. (In "Fridtjof Nansen, 1891-93," von W. C. Broger \& N. Rolfsen. Deutsch v. Eugen v. Enzberg. Berlin, 1896. Anhang. zur deutschen Ansgabe, pp. 415-422.)

1897. Die Ziele der Südpolarforschung. In Verh. Erdk., Leipzig, 1896 (1897), xxxix.-xliii.

" Grönland Expedition der Gesellschaft für Erdkunde zu Berlin, 1891-93.

1898. Die Aufgaben der Forschung am Nordpol und Südpol, 1898. G. Z., Leipzig, 4 (1898), 121-133.

1899. Plan und Aufgaben dęr Deutschen Sudpolar Expedition. Verh. Ges. Erdk., Berlin, 26 (1899), 452-463.

, Gemeinschaftliche Sitzung der Gesellschaft für Erdkunde zu Berlin und der Abteilung Berlin-Charlottenburg der Deutschen Kolonial-Gesellschaft am 16. Jan. 1899. Tagesordnung: Die geplante Deutsche Südpolar Expedition. Vortrag von Dr. v. Drygalski. Bemerkungen von Geh.Reg.-Rat. v. Berzold. (Contains also speeches by Freiherr F. von Richthofen and Prinz von Arenberg.) Verh. Ges. Erdk., Berlin, 26 (1899), 58-87.

"Ueber die wissenschaftliche, praktische und nationale Bedeutung, der deutschen Südpolar Expedition. Naturw, Wochenschrift, Berlin, 14 (1899), 477-483. May.

1900. The German Antarctic Expedition. 'Nature,' London, 61 (1900), 316-327.

THE WORK AND EQUIPMENT FOR EARTH MAGNE'IISM AND : METEOROLOGY OF THE GERMAN SOUTH POLAR EXPEDITION, AND SUGGESTIONS FOR INTERNATIONAL CO-OPERATION DURING THE TIME OF THE SOUTH POLAR RESEARCH, 1901-1903.

\section{By Dr. Fr. Bidlingdaier.}

AT this time, when the German South Polar Expedition is on the point of leaving home, it would be of interest to give an account of the work a to be done in Earth Magnetism and Meteorology by the Expedition, and also the equipment at disposal, and further, to discuss to what extent an international co-operation is practicable during the period of South Polar research.

Germany will set up two stations for the year 1902-1903, namely, a chief station in the Antarctic regions, with Dr. Fr. Bidlingmaier as observer, and a branch station on Kerguelen Island, with Dr. Karl Luyken as observer.

\section{The Magnetic Work.}

1. Ship's Observations.-During the journey, both to and from the Antarctic, every day as far as possible a complete determination of all three elements will be taken. Besides, through complete deviationdetermination, before the departure, off St. Vincent, off Ascension, Cape of Good Hope, Kerguelen, and in the Antarctic, the influence of the ship's body on all three elements will be fixed. 
Instruments.-(1) A strongly built swinging table to stand on the bridge; (2) a Fox apparatus of the Captain Creak pattern, Admiralty, London; (3) a complete deviation-magnetometer, by Bamberg; (4) a normal compass of the first grade, and a steering compass.

2. Observations on Land.-At both stations (1) the progress of all three elements will be followed for at least a year by means of photographic registration and directly by variation instruments. (2) The record of the variation instruments will be controlled as occasion demands by absolute measurement and reduced to absolute scale. (3) By journeys from the station the neighbourhood will be measured magnetically. .

Both stations are furnished with a variation house, in which particular care will be taken to preserve a constant temperature; and a small house for absolute measurements. Both stations are provided with the following instruments: (1) A magnetic theodolite, by Tesdorpf in Stuttgart, with a swing box and an inclinator for the determination of total intensity. This is the chief instrument of the Antarctic station, and there is none at Kerguelen. (2) Another of the same, but simpler, and fit for taking on a journey. (3) An earth-induction instrument of the Wild pattern by Schulze in Potsdam. (4) Two sets of variometers for the three instruments; with accessories (Kerguelen, one set), by Töpfer in Potsdam. (5) Two registration apparatus to go two or twenty-four hours, with accessories. (6) A galvanometer.

3. In connection with the magnetic work, possibly the following observations will be made: The electric phenomena of the air; the Polar lights, their form, changes, and height, spectrum. Instruments provided: (1) Several Exners electroscopes; (2) a complete distribution apparatus after Elster and Geitel ; (3) two simple theodolites with adjustment for parallax determination; (4) a complete spectograph.

\section{The Meteorological Work.}

1. The Ship's Observations. -Will be taken in the usual way once every watch. Besides, atmospheric pressure, temperature, and humidity will be continuously registered. For the investigation of the higher strata of the atmosphere kites will be employed, with the usual self-registering apparatus.

2. Observations on Land.-To be carried on at both stations. Direct observations to be made at three fixed periods every day about 7 A.M., 2 P.M., 9 P.M., local time, and observations of all branches of meteorology, according to necessity, wind, clouds, sky, etc. (2) Continuous record of atmospheric pressure, temperature, humidity, and duration of sunshine. (3) By means of kites at the Antarctic chief station, as far as is practicable, atmospheric pressure, temperature, humidity, direction and strength of wind of the upper regions will be observed.

The Antarctic head station is provided with the following instruments, while the Kerguelen station has the same sort of instruments nearly though not all of the same kind.

(1) Atmospheric pressure.-Two ship's barometers, a normal and a 
station barometer, each with a reserve tube; two aneroidbarographs to go for seven or two days ; five aneroids of different degrees of sensitiveness; a thermohypsometer, with several reserve thermometers.

(2) Wind.-Four pocket anemometers; two wind vanes, with strength indicators.

(3) Temperature.-Twenty Schleuder thermometers; twenty Psychrothermometers, with mercury and alcohol; fifteen maximum and fifteen minimum thermometers; a set of ordinary ground thermometers for depths of $5,20,50,100,200 \mathrm{~cm}$; a set of electric ground thermometers; three common black bulb thermometers; three black bulb thermometers as maximum thermometers; an aspiration psychrometer, with accessories; two thermographs to go for seven and two days.

(4) Humidity.--Two capillary hygrometers (Koppe); a Lambrecht polymeter; two hygrographs (Richard); two condensation hygrometers (Lambrecht).

(5) Sunshine duration.-Two sunshine self-registering apparatus, one of Campbell-Stokes pattern, the other of Jordan pattern.

(6) Kite observations. - A number of kites, of Hargrave and Eddy types; two meteorographs of Marvin type; two baro-thermo-hygroanemo-graphs by Richard.

(7) Measurement of height of clouds.-Two simple theodolites.

For the German and the simultaneous English South Polar Expeditions, international co-operation has been suggested, and after agreement between a German and an English committee, the following programme has been drawn up.

\section{Programmie for the International Co-operation in Earth-Magnetish Odservations.}

1. The object of this is to furnish science with a large number of details sufficient to permit of a study of the changes in the magnetic condition of the earth in its totality over a given fixed period of time, and which will lay the foundations from which alone we can hope to settle the fundamental questions of earth-magnetism.

2 . The stations for observation which intend to co-operate are distributed all over the whole world with a uniformity never attained till now.

3. The observations are all to be simultaneous over the whole world. They are of two kinds. These are: (1) observations of the three elements for a whole hour on certain fixed days in order to get a view of the progress of the daily variation of the whole magnetism of the earth ; (2) close observations of the three elements during a fixed hour of each day fixed on, in order to follow the progress of the individual disturbances.

4. All observations will be made by means of Greenwich time at all the co-operating stations.

5. It is desired that the electric phenomena of the air and the aurora be carefully noted on the days fixed on, and that the observations be entered up on the observation-sheets under the heading "Remarks." 
6. The office of the Seventh International Geographical Congress at Berlin will provide all co-operating stations with a sample of the observation formula, and recommends its universal adoption.

IV. Programine for the International Co-operation IN Meteorological Observations.

1. The object of this is the construction of a synoptical weather chart of the as yet little-known southern latitudes for every day in the periods of time agreed upon, an object of particular importance from a theoretical as well as a practical standpoint.

2. All co-operating stations south of $30^{\circ} \mathrm{S}$, all states with permanent or temporary meteorological observatories south of $30^{\circ} \mathrm{S}$., all states and commercial bodies whose ships will be at sea south of $30^{\circ} \mathrm{S}$. during the period fixed upon are requested to see that meteorological observations be taken from 1 st October 1901 to 31 st March 1903, every day at midday by Greenwich time.

3. The observations to be confined to precise records: (1) of the time of observation (local time); (2) place of observation; (3) atmospheric pressure; (4) air temperature; (5) strength and direction of wind; (6) the clouds, kind, amount, and arrangement. With regard to the latter point, the higher clouds (Cirri) are particularly to be noted.

4. The office of the Seventh International Geographical Congress should provide all the states co-operating with a sample of the observation formule and the notation to be employed, and recommend its general adoption.-_Petermann's Mitteilungen, July 1901.

\title{
THE BACTERIOLOGICAL WORK OF THE GERMAN SOUTH POLAR EXPEDITION.
}

\author{
By Dr. HaNs Gazert.
}

THE extraordinary important rôle which micro-organisms play in the economy of nature makes it desirable, that these minute though vastly important creatures should not be overlooked among the biological investigations of the German South Polar Expedition. The most important function they perform is the destruction of decaying organic material, and the conversion of it into that form which best serves to nourish plant life, and thus indirectly all organic life. To what extent this destructive process goes on in the Frigid zone is the chief object of investigation of the bacteriologist of the expedition. The notion that the low temperature of the Polar regions hinders the growth of bacteria is only partly correct. Ships have many a time come on the dead and highly decomposed bodies of whales, and have noticed the presence of skeletons in Polar regions. The decomposition of the flesh of animals that have been slaughtered has been noted by many expeditions, and goes to prove the presence of microbes. It is quite inconceivable that they could be absent in a region with a rich growth of vegetation as in the north of Greenland and in Spitzbergen, where, indeed, large carnivores, 